\title{
Productivity, profitability and nutritional quality of forage and silage of winter cereals
}

\section{Produtividade, rentabilidade e qualidade nutricional da forragem e da silagem de cereais de inverno}

\author{
Mikael Neumann ${ }^{1}$; André Dochwat ${ }^{2}$; Egon Henrique Horst ${ }^{3}$; Bruno Jose Venancio ${ }^{4}$; \\ Jony Cley Santos ${ }^{5}$; Julio Cezar Heker Junior ${ }^{6 *}$; Fernando Braga Cristo ${ }^{7}$; Leslei \\ Caroline Santos ${ }^{8}$; Emylli Pereira e Silva ${ }^{9}$
}

\begin{abstract}
This study aimed to evaluate the production, the physical and nutritional composition of forage and silage, as well as the profitability and aerobic stability of different winter cereals harvested at the stage of floury grain. The experimental design was a $2 \times 7$ factorial randomized block design, with two forms of foods (fresh forage and silage) and seven genotypes, with four replications. The genotypes used were the white oat (Avena sativa) cv. URS Taura; barley (Hordeum vulgare) cv. BRS Brau and cv. BRS Cauê; wheat (Tricticum aestivum) cv. CD 1440; rye (Secale cereal) cv. BR 01; and triticale (X Triticosecale) cv. IPR 111 and cv. BRS Saturno. The materials were harvested during the stage of floury grain. In forage evaluation, rye showed the highest $(\mathrm{P}<0,05)$ dry biomass production $\left(7,100 \mathrm{~kg} \mathrm{ha}^{-1}\right)$, but with a higher percentage of stem (46.7\%) in dry matter, implying higher ADF $(44.69 \%)$ in relation to other cereals. The forage of the white oats cv. URS Taura and triticale cv. IPR 111 provided the best nutritional quality compared to the other evaluated cereals, but in the resulting silage, only triticale remained with forage-like characteristics. It was clear the superiority of barley cv. BRS Cauê, wheat cv. CD 1440 and rye cv. BR 01 regarding the maintenance of aerobic stability (160 hours), while the other silages lost their stability within 32 hours. Rye cv. BR 01 and triticale IPR 111 presented the highest production of recovered dry biomass (5,402 and 5,352 $\mathrm{kg} \mathrm{ha}^{-1}$ respectively), barley cv. BRS Cauê and oat URS Taura provided higher cost of production per $\mathrm{kg}^{-1}$ dry biomass, both with $\mathrm{R} \$ 0.29$ and higher cost per $\mathrm{kg}$ of recovered dry biomass $\mathrm{R} \$ 0.45$ and 0.37 respectively. There are several factors to consider when choosing the winter species for silage production, and future studies can fully elucidate these factors.

Key words: Aerobic stability. Floury grain. Morphological composition. Production of dry biomass.
\end{abstract}

\footnotetext{
1 Eng ${ }^{\circ}$ Agro ${ }^{\circ}$ Dr., Pesquisador do NUPRAN (Núcleo de Produção Animal), Pesquisador Produtividade PQ/CNPq, Prof., Curso de Pós- Graduação em Agronomia na área de Produção Vegetal e em Ciências Veterinárias na área de Produção e Saúde Animal Sustentável, Universidade Estadual do Centro-Oeste, UNICENTRO, Centro de Ciências Agrárias e Ambientais da, Guarapuava, PR, Brasil. E-mail: neumann.mikael@hotmail.com

2 Médico Veterinário, M.e em Produção Vegetal, UNICENTRO, Guarapuava, PR, Brasil. E-mail: andre.dochwat@hotmail.com

3 Médico Veterinário, M.e, Discente de Doutorado em Ciência Animal, Universidade Estadual de Londrina, UEL, Londrina, PR, Brasil. E-mail: egonhh@yahoo.com.br

4 Médico Veterinário, M.e em Ciências Veterinárias, UNICENTRO, Guarapuava, PR, Brasil. E-mail: bru.ze.venancio@gmail.com

5 Eng ${ }^{\circ}$ Agro , Dr.em Produção Vegetal, UNICENTRO, Guarapuava, PR, Brasil. E-mail: jony_cley@yahoo.com.br

6 Médico Veterinário, M.e, Discente de Doutorado em Produção Vegetal, UNICENTRO, Guarapuava, PR, Brasil. E-mail: jr_ heker@hotmail.com

7 Médico Veterinário, Discente de Mestrado em Ciências Veterinárias, UNICENTRO, Guarapuava, PR, Brasil. E-mail: fernandobragacristo@gmail.com

8 Médica Veterinária, M.e, Discente de Doutorado em Zootecnia, Universidade Estadual do Oeste, UNIOESTE, Marechal Candido Rondon, PR, Brasil. E-mail: lesleicaroline@hotmail.com

9 Eng $^{\mathrm{a}} \mathrm{Agr}^{\mathrm{a}}$, Centro Universitário Campo Real, Guarapuava, PR, Brasil. E-mail: emylli.pe95@gmail.com

* Author for correspondence
} 


\section{Resumo}

O objetivo do trabalho foi avaliar a produção, a composição física e nutricional da forragem e da silagem, bem como a rentabilidade e a estabilidade aeróbia, de diferentes cereais de inverno colhidos em estádio de grão farináceo. O delineamento experimental utilizado foi o de blocos ao acaso, em esquema fatorial $2 \times 7$, sendo dois alimentos (forragem e silagem) e sete genótipos, com quatro repetições. Os genótipos utilizados foram a aveia branca (Avena sativa) cv. URS Taura; cevada (Hordeum vulgare) cv. BRS Brau e cv. BRS Cauê; trigo (Triticum aestivum) cv. CD 1440; centeio (Secale cereale) cv. BR 01; e triticale ( $X$ Triticosecale) cv. IPR 111 e cv. BRS Saturno. A colheita de todos os materiais ocorreu em estádio de grão-farináceo. Na avaliação das forragens, o centeio apresentou a maior $(\mathrm{P}<$ $0,05)$ produção de biomassa seca $\left(7.100 \mathrm{~kg} \mathrm{ha}^{-1}\right)$, porém com maior participação de colmo $(46,7 \%)$ na matéria seca, implicando em maior teor de FDA (44,69\%) em relação aos demais cereais. A forragem da aveia branca cv. URS Taura e do triticale cv. IPR 111 proporcionaram a melhor qualidade nutricional frente aos demais cereais avaliados, porém, na silagem resultante, apenas o triticale manteve-se com características semelhantes à forragem. Ficou evidenciado a superioridade da cevada cv. BRS Cauê, do Trigo cv. CD 1440 e do centeio cv. BR 01 quanto a manutenção da estabilidade aeróbia (160 horas), ao passo que as demais silagens perderam sua estabilidade em 32 horas. O centeio cv. BR 01 e o triticale IPR 111 apresentaram a maior produção de biomassa seca recuperada (5.402 e $5.352 \mathrm{~kg} \mathrm{ha}^{-1}$ respectivamente), a cevada cv. BRS Cauê e Aveia URS Taura proporcionaram maior custo de produção por $\mathrm{kg}^{-1}$ de biomassa seca ambas com $\mathrm{R} \$ 0,29$ e maior custo por $\mathrm{kg}$ de biomassa seca recuperada $\mathrm{R} \$$ 0,45 e 0,37 respectivamente. São vários os fatores a serem considerados no momento da escolha da espécie hibernal com vistas a produção de silagem a ser cultivada, onde estudos futuros podem elucidar completamente estes fatores.

Palavras-chave: Composição morfológica. Estabilidade aeróbia. Grão farináceo. Produção de biomassa seca.

\section{Introduction}

The winter cereal cultivation for animal feeding, whether it is forage or silage, is an excellent tool in certain regions of the country, but poorly explored. According to Meinerz et al. (2011a), among the cereals cultivated, stand out the oat (Avena sativa), the barley (Hordeum vulgare), the wheat (Triticum aesetivum), the rye (Secale cereal) and the triticale (X Triticosecale) as options of excellent nutritional quality.

The winter cereals usually have low energy contents, but greater levels of crude protein compared to corn silage (MEINERZ at al., 2011b), what makes them complementary in a diet. Floss et al. (2007) quote that winter cereal forages at the pre-flowering stage have higher levels of crude protein in relation to the forage in level of floury grain $(18.9 \%$ against $8.9 \%)$, but the latter contains higher concentrations of starch in its composition, resulting in a more caloric feed, besides facilitating the operation with harvesting direct to the ensiling process, not requiring pre-drying in the field.

However, the qualitative and quantitative characteristics of forage and subsequent silage produced by winter cereals are dependent on several factors, such as variability between species, between genotypes of the same species and their adaptability to different soil and climatic conditions (HORST, 2016). Therefore, to better choose which winter cereal for cultivation, it is necessary to consider the productivity, nutritional quality and profitability of each

Based on this context, the objective of this study was to evaluate the production, the physical and nutritional composition of forage and silage, as well as the profitability and the aerobic stability of different winter cereals harvested at the stage of floury grain. 


\section{Material and Methods}

The experiment was conducted by the Animal Production Center - APC (Núcleo de Produção Animal - NUPRAN) along with the Course of Masters in Agronomy in Vegetal Production area, belonging to the sector of Agricultural and Environmental Sciences from the Universidade Estadual do Centro-Oeste (UNICENTRO), located in the city of Guarapuava, state of Paraná, in the subtropical zone of the state, at the geographic coordinates $25^{\circ} 23^{\prime} 02^{\prime \prime} \mathrm{S}$ latitude and $51^{\circ} 29^{\prime} 43^{\prime \prime} \mathrm{W}$ longitude and $1.026 \mathrm{~m}$ altitude.
The region climate is, according to Köppen classification, $\mathrm{Cfb}$ (Humidmesothermal subtropical), with mild summer and moderate winter, without a well-defined dry season and with severe frosts. The annual average rainfall is $1.944 \mathrm{~mm}$, annual average minimum temperature of $12.7^{\circ} \mathrm{C}$, annual average maximum temperature of $23.5^{\circ} \mathrm{C}$ and air relative humidity of $77.9 \%$. Figure 1 illustrates the average rainfall in $\mathrm{mm}$ and insolation in hours day ${ }^{-1}$, as well as the maximum and minimum temperature in ${ }^{\circ} \mathrm{C}$ and the relative air humidity in $\%$, in decades, during the experimental period.

Figure 1. Mean of rainfall $(\mathrm{mm})$, insolation $\left(\right.$ hours day $\left.{ }^{-1}\right)$, maximum and minimum temperature $\left({ }^{\circ} \mathrm{C}\right)$ and air relative humidity (\%), in the period of winter cereals cultivation.

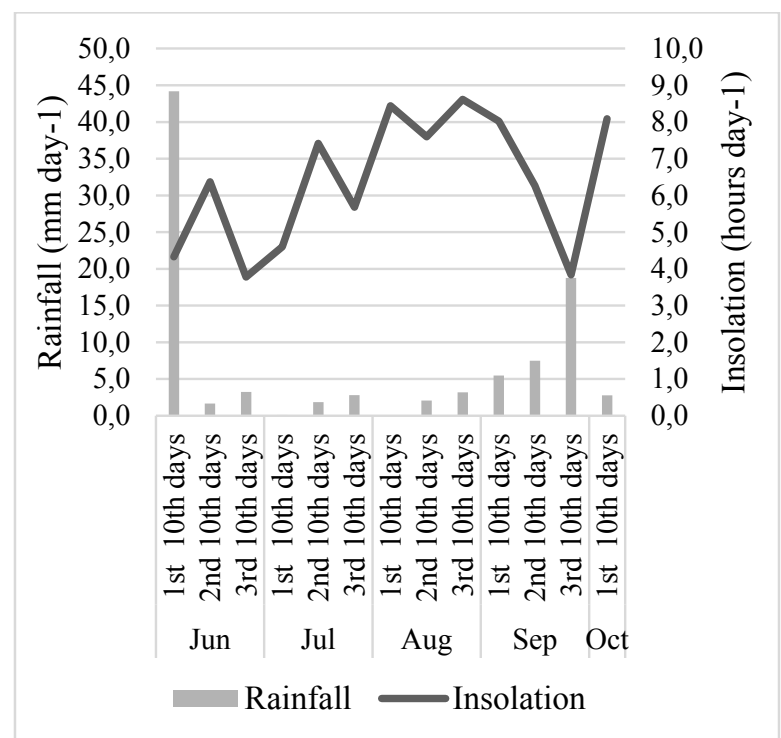

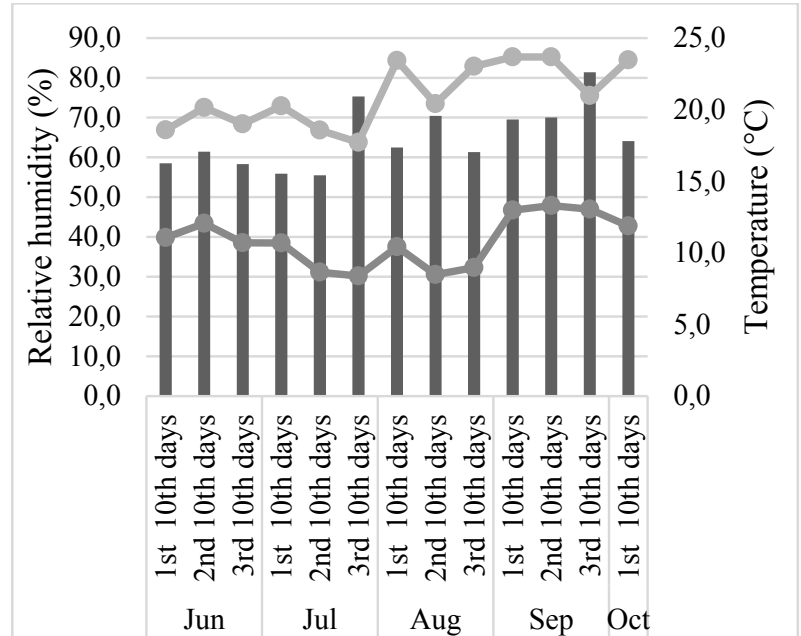

Relative humidity - Max. Temp. $\longrightarrow$ Min. Temp.

Source: Experimental station from SIMEPAR/UNICENTRO, Guarapuava, PR, 2014.

The soil of the experimental area was classified as Typical Latosol Bruno (POTT, 2007), and upon the implementation of crops showed the following chemical characteristics (profile from 0 to $20 \mathrm{~cm}$ ): $\mathrm{pH}$ in $0.01 \mathrm{CaCl}_{2}: 4.7$; $\mathrm{P}: 1.1 \mathrm{mg} \mathrm{dm}^{-3} ; \mathrm{K}^{+}: 0.2$ cmolc $\mathrm{dm}^{-3}$; OM: $2.62 \mathrm{~g} \mathrm{dm}^{-3} ; \mathrm{Al}^{3+}: 0.0$ cmolc dm${ }^{-3} ; \mathrm{H}^{+}+$ $\mathrm{Al}^{3+}: 5.2$ cmolc dm${ }^{-3} ; \mathrm{Ca}^{2+}: 5.0$ cmolc dm${ }^{-3} ; \mathrm{Mg}^{2+}$ : $5.0 \mathrm{cmolc} \mathrm{dm}^{-3}$ and base saturation (V\%): $67.3 \%$.
Winter cereals were sown according to agricultural zoning for the region of Guarapuava, under no-tillage system. The sowing was performed with 0.17-meter row spacing, mean seed depth of two centimeters, and sowing density of 300 seeds $\mathrm{m}^{2}$. The total experimental area consisted of $570 \mathrm{~m}^{2}$, distributed in 48 plots of $9 \mathrm{~m}^{2}$ each $(4.00 \mathrm{~m} \times 2.25$ $\mathrm{m})$, where each plot represented an experimental unit. 
The experimental design was a $2 \times 7$ factorial randomized block design, with two forms of foods (fresh forage and silage) and seven genotypes, with four repetitions. The genotypes used were the white oat (Avena sativa) cv. URS Taura; barley (Hordeum vulgare) $c v$. BRS Brau e cv. BRS Cauê; wheat (Triticum aestivum) cv. CD 1440; rye (Secale cereal) $c v$. BR 01; and triticale (X Triticosecale) $c v$. IPR 111 and $c v$. BRS Saturno.

Upon sowing, it was used basal fertilization of $400 \mathrm{~kg} \mathrm{ha}^{-1}$ of the 04-20-20 (N-P $\left.\mathrm{O}_{5}-\mathrm{K}_{2} \mathrm{O}\right)$ fertilizer, respecting the recommendations from the soil fertility commission of Santa Catarina and Rio Grande do Sul (CQFS RS/SC, 2004). The nitrogen topdressing was made in two applications, the first 30 days after planting with 140 ha $^{-1}$ urea (46-00-00), and the second application 30 days after the first, with $250 \mathrm{~kg} \mathrm{ha}^{-1}$ urea (46-00-00), totaling $191.5 \mathrm{~kg}$ nitrogen $\mathrm{ha}^{-1}$.

Weeds were controlled chemically with the use of herbicide, formulated with Glyphosate (Roundup commercial product $\mathrm{WG}^{\circledR}: 3.0 \mathrm{~kg} \mathrm{ha}^{-1}$ ) for desiccation in the experimental area 15 days before sowing and in the crop management, 30 days after planting, with the application of metsulfuronmethyl based herbicide (commercial product Ally ${ }^{\circledR}$ : $\left.6.6 \mathrm{~g} \mathrm{ha}^{-1}\right)$.

The economic analysis consisted of the determination of the amount of the relative investment to the establishment and management of the crops, considering the value for seed purchase of each cultivar (white oat cv. URS Taura: 1.00 R\$ $\mathrm{kg}^{-1}$; barley cv. BRS Brau: $1.50 \mathrm{R} \$ \mathrm{~kg}^{-1}$ and cv. BRS Cauê: $1.60 \mathrm{R} \$ \mathrm{~kg}^{-1}$; wheat cv. CD 1440: $1.74 \mathrm{R} \$$

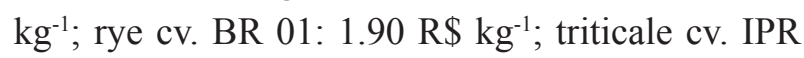

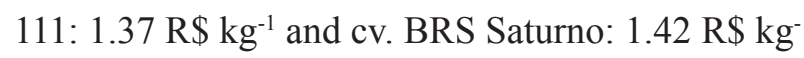
$\left.{ }^{1}\right)$, herbicide for desiccation (10.40 R $\left.\$ \mathrm{~kg}^{-1}\right)$, post emergence herbicide (1.11 $\left.\mathrm{R} \$ \mathrm{~g}^{-1}\right)$, fertilizer 04-2020 (N-P2O5-K2O) (1,40 R \$ kg-1) and urea 46-00-00 (N-P2O5-K2O) (1.53 R\$ kg-1). In this way, the dry biomass cost was measured through the relationship between the investment $\mathrm{R} \$ \mathrm{ha}^{-1}$ of the crop and the dry biomass production, in $\mathrm{kg} \mathrm{DM} \mathrm{ha}^{-1}$.

The plants were manually harvested at $10 \mathrm{~cm}$ from the ground at the floury grain stage, according to scale of development for winter cereals, suggested by Large (1954).

A homogeneous sample of each material during harvest was sent to the laboratory for the plant physical composition analysis. This practice allowed to determine the percentage composition of the plant anatomic structures by the separation of the physical components into stem, leaves and cob or panicle.

Soon after the harvest, the material was chopped and ensiled in laboratory silos made of polyvinyl with $45 \mathrm{~cm}$ height and $10 \mathrm{~cm}$ diameter. The material was manually compacted to a specific mass of 300 $\mathrm{kg} \mathrm{DM} \mathrm{m}^{2}$. After filling the silos, they were sealed, identified, weighed and stored.

After the forage cutting and also after opening the silos, 45 days after silage making, homogeneous samples from each material were sent to the laboratory to determine the dry matter content, using forced air ventilation oven at $55^{\circ} \mathrm{C}$, where the samples remained until constant weight. The relationship between the material harvested and the plot area unit allowed to estimate the production of green biomass $\left(\mathrm{kg} \mathrm{ha}^{-1}\right)$ and dry biomass $\left(\mathrm{kg} \mathrm{ha}^{-1}\right)$. Then, the pre-dried samples of the original material were ground in a Wiley mill, with a sieve of $1 \mathrm{~mm}$.

In the pre-dried samples, sequentially, samples were analyzed for the mean content of crude protein $(\mathrm{CP})$ by the micro Kjeldahl method and the mineral matter $(\mathrm{MM})$ by incineration at $550^{\circ} \mathrm{C}(4$ hours), as well as for neutral detergent fiber (NDF), using $\alpha$ thermostable amylase (Termamyl 120L, Novozymes Latin América Ltda.) and acid detergent fiber (ADF), following methodologies described by Silva and Queiroz (2009). From the said values, the levels of hemicellulose (HEM) were estimated by difference between NDF and ADF. The total content of digestible nutrients (TDN, \%) was obtained by 
the equation $[\mathrm{TDN}, \%=87.84-(0.70 \mathrm{x} \mathrm{ADF})]$, both suggested by Bolsen (1996).

When the silos were opened, it was possible to determine the dry matter recovery by the equation: $\mathrm{RDM}=[(\mathrm{MFf} \times \mathrm{DMf}) /(\mathrm{MFi} \times \mathrm{DMi})] \times 100$, where: $\mathrm{RDM}=$ recovery of $\mathrm{DM}(\%) ; \mathrm{MFi}=$ mass of ensiled forage $(\mathrm{g})$; DMi $=\mathrm{DM}$ content of ensiled forage $(\%)$; $\mathrm{MFf}=$ silage $\operatorname{mass}(\mathrm{g})$; DMf $=$ silage DM content $(\%)$.

The aerobic stability evaluation was obtained through temperature measurements, which began after opening the silos. In each silo, the silage was stirred to facilitate exposure of the ensiled material to the atmospheric air, according to Kung Junior et al. (2000), and a sample of $400 \mathrm{~g}$ of the material was placed in containers with $4 \mathrm{~kg}$ capacity. The silages in the containers were exposed to the atmospheric air for 168 hours, in a room with a controlled constant temperature of $25^{\circ} \mathrm{C}$ throughout the experimental period. To determine the aerobic stability of the silages, the temperature was read daily at $06 \mathrm{~h} 00$ a.m., 12 h00 p.m. and 06h00 p.m., using a digital long stem thermometer, Gulterm 1001, at the center of the forage mass. The standard for the breaking of the aerobic stability definition was considered when the temperature of the ensiled material exceeded in $2^{\circ} \mathrm{C}$ the environmental temperature, according to Taylor and Kung Junior (2002).

The rumen dry matter degradability (DMD) was determined by the in situ technique, using nylon bags with $12 \mathrm{cmx} 8 \mathrm{~cm}$ and pore sizes from 40 to
$60 \mu \mathrm{m}$, which contained $5 \mathrm{~g} \mathrm{DM}$, milled to $1 \mathrm{~mm}$, for later incubation in rumen (NOCEK, 1988). The incubation time used was 48 hours. For that, two 36-month-old calves were used, average body weigh of $600 \mathrm{~kg}$, with ruminal fistula.

Data were subjected to Shapiro-Wilk and Bartlett tests, to check the assumptions of normality and homoscedasticity, respectively. Once these assumptions were met, we applied the F-test with 5\% probability with the analysis of variance (ANOVA) and, when difference was found, the Tukey's test was applied to compare the multiple means with 5\% significance, using the SAS software (1993).

\section{Results and Discussion}

Rye forage showed the highest production of dry biomass $\left(7,100 \mathrm{~kg} \mathrm{ha}^{-1}\right)$, not differing only from triticale IPR 111(6,921 $\mathrm{kg} \mathrm{ha}^{-1}$ ) (Table 1). Comparing rye and the white oat, it was found a difference of $40.52 \%$ in dry biomass production, totalizing 2,877 $\mathrm{kg} \mathrm{ha}^{-1}$. In a comparison between rye and white oats, a difference of $40.52 \%$ in dry biomass production ha-1 was observed, totaling $2,877 \mathrm{~kg}$ ha- 1 . Results described by Lehmen et al. (2014) also highlight the high productive potential of rye when harvested for forage. The same authors point out that the production of dry biomass in addition to being directly related to intrinsic factors of each genotype, the cycle of each forage can directly interfere in the results, as all genotypes were implanted on the same date may have reflected in the results.

Table 1. Production of dry biomass, forage and silage DM content, planting investment and costs of production of forage dry biomass.

\begin{tabular}{|c|c|c|c|c|c|}
\hline \multirow{2}{*}{ Genotype } & Dry biomass & Forage DM & Silage DM & Investment & Cost of production \\
\hline & $\mathrm{kg} \mathrm{ha}^{-1}$ & ----------- \% & ------------ & $\mathrm{R} \$ \mathrm{ha}^{-1}$ & $\mathrm{R} \$ \mathrm{~kg}$ of $\mathrm{DM}^{-1}$ \\
\hline White oat - URS Taura & $4.223 \mathrm{c}$ & $57,3 \mathrm{c}$ & $61,8 \mathrm{ab}$ & $1.232,34$ & $0,29 \mathrm{a}$ \\
\hline Barley - BRS Brau & $5.625 \mathrm{~b}$ & $55,7 \mathrm{c}$ & $53,2 \mathrm{~b}$ & $1.252,34$ & $0,22 \mathrm{~b}$ \\
\hline Barley - BRS Cauê & $4.306 \mathrm{c}$ & $73,1 \mathrm{a}$ & $61,8 \mathrm{ab}$ & $1.256,34$ & $0,29 \mathrm{a}$ \\
\hline
\end{tabular}


continuation

\begin{tabular}{lccccc} 
Wheat - CD 1440 & $5.505 \mathrm{~b}$ & $70,2 \mathrm{a}$ & $69,6 \mathrm{a}$ & $1.261,94$ & $0,23 \mathrm{~b}$ \\
Rye - BR 01 & $7.100 \mathrm{a}$ & $59,0 \mathrm{bc}$ & $60,1 \mathrm{ab}$ & $1.268,34$ & $0,18 \mathrm{~b}$ \\
Triticale - IPR 111 & $6.921 \mathrm{a}$ & $63,5 \mathrm{~b}$ & $61,2 \mathrm{ab}$ & $1.247,14$ & $0,18 \mathrm{~b}$ \\
Triticale - BRS Saturno & $6.462 \mathrm{ab}$ & $63,0 \mathrm{~b}$ & $60,5 \mathrm{ab}$ & $1.193,76$ & $0,19 \mathrm{~b}$ \\
\hline Average & 5.735 & 63,12 & 61,2 & $1.252,51$ & 0,22 \\
CV, \% & 8,51 & 4,49 & 9,51 & - & 10,00 \\
$\mathrm{P}>$ & $<0,0001$ & $<0,0001$ & 0,0177 & - & $<0,0001$ \\
\hline
\end{tabular}

Means followed by different lowercase letters, in the same column, are significantly different by Tukey’s test at $5 \%$.

There was a difference $(\mathrm{P}<0.05)$ between forages evaluated for cost of production, where the white oats cv. URS Taura and barley cv BRS Cauê differed from the other forages with the higher costs per kg dry biomass, both with $\mathrm{R} \$ 0.29$ per $\mathrm{kg}$ of produced dry biomass.

For the forage dry matter content, we observed distinct values between genotypes, which varied from $55.7 \%$ to $73.1 \%$ (Table 1 ). The highest values were found for barley cv. BRS Cauê and wheat CD 1440. It is important to emphasize that the dry matter content directly affects the fermentative quality of the silage, which is related to both the intake potential and to the efficiency of nutrient utilization.
This variable at the harvest time is a parameter that suffers influence from several factors, mainly from the hydration degree of plant components, which depends on the nutritional status and on the biotype and abiotic stresses suffered by the plant during its growth (WOOLFORD; PAHLOW, 1998).

The content of dry matter of the silage after opening the silos showed a mean value of $63.12 \%$, where the highest values were found for barley cv. BRS Cauê and wheat cv. CD 1440 with 73.1 and $70.2 \%$, respectively (Table 1 ). The importance of measuring the dry matter of the forage and the silage allows to assess the dry matter recovery after opening the silos (Table 2).

Table 2. Recovery of silage DM, production of recovered dry biomass and cost per kg of recovered dry biomass of winter cereals harvested at the stage of floury grain.

\begin{tabular}{lccc}
\hline \multirow{2}{*}{ Genotype } & DM recovery & Recovered dry biomass & Cost of production \\
\cline { 2 - 4 } & $\%$ & $\mathrm{~kg} \mathrm{ha}^{-1}$ & $\mathrm{R} \$ \mathrm{~kg} \mathrm{DM}$ \\
\hline White oat - URS Taura & $82.1 \mathrm{a}$ & $3,491 \mathrm{dc}$ & $0.37 \mathrm{ab}$ \\
Barley - BRS Brau & $75.0 \mathrm{a}$ & $4,213 \mathrm{abc}$ & $0.30 \mathrm{bc}$ \\
Barley - BRS Cauê & $66.4 \mathrm{a}$ & $2,864 \mathrm{~d}$ & $0.45 \mathrm{a}$ \\
Wheat - CD 1440 & $73.8 \mathrm{a}$ & $4,052 \mathrm{bc}$ & $0.31 \mathrm{bc}$ \\
Rye - BR 01 & $76.4 \mathrm{a}$ & $5,402 \mathrm{a}$ & $0.23 \mathrm{c}$ \\
Triticale - IPR 111 & $77.3 \mathrm{a}$ & $5,352 \mathrm{a}$ & $0.23 \mathrm{c}$ \\
Triticale - BRS Saturno & $73.4 \mathrm{a}$ & $4,726 \mathrm{abc}$ & $0.27 \mathrm{bc}$ \\
\hline Average & 74.87 & 4,299 & 0.30 \\
CV, \% & 10.07 & 11.48 & 16.18 \\
P> & 0.3175 & $<0.0001$ & $<0.0001$ \\
\hline
\end{tabular}

Means followed by different lowercase letters, in the same column, are significantly different by Tukey's test at $5 \%$. 
The dry matter recovery (Table 2) was the only variable with no significant difference between silages. After corrections for production of recovered dry biomass, after the losses by fermentation, rye cv. BR 01 and triticale cv. IPR 111 showed superiority when compared to the other silages, with 5,402 and 5,352 $\mathrm{kg}$ dry biomass ha-1 ${ }^{-1}$, respectively. On the other hand, barley cv. BRS Cauê and white oat cv. URS Taura obtained the smaller productions, with 2,864 and 3,491 kg dry biomass ha ${ }^{-1}$, however oats did not differ $(\mathrm{P}<0,05)$ from barley cv. BRS Brau, from wheat cv. CD 1440 and from triticale cv. BRS Saturno, with 4,213, 4,052 and 4,726 kg dry biomass $\mathrm{ha}^{-1}$, respectively.

Most of literature data emphasize and compare the winter cereals only in biomass production at the harvest time and do not correlate them to the possible losses during the ensiling process (MEINERZ et al., 2011b), being clear that the real value consists of the amount of dry biomass destocking of silo.

The costs for kilo dry biomass recovered were smaller for rye cv. BR 01 and triticale cv. IPR 111, which is a direct reflex of their productivity and recovery of dry matter above the average of these materials, where we observed $\mathrm{R} \$ 0.23$ per $\mathrm{kg}$ of recovered dry biomass.

In relation to the physical composition of the forages, there was a significant difference and rye showed the highest participation of stem (46.7\%) (Table 3), implying in a ADF content higher than the overall mean (Table 4), since this is a portion rich in cellulose and lignin. Consequently, the rye showed the smallest $(\mathrm{P}<0.05)$ participation of cob (42.1\%).

Table 3. Physical composition of different winter cereals and the respective dry matter contents harvested at the floury stage.

\begin{tabular}{lcccccc}
\hline & \multicolumn{3}{c}{ Plant structure (\% in DM) } & \multicolumn{2}{c}{ DM content of components (\%) } \\
\cline { 2 - 7 } Genotype & Stem & Leaf & $\begin{array}{c}\text { Reproductive } \\
\text { structure }\end{array}$ & Stem & Leaf & $\begin{array}{c}\text { Reproductive } \\
\text { structure }\end{array}$ \\
\hline White oat - URS Taura & $35.1 \mathrm{~b}$ & $17.2 \mathrm{ab}$ & $53.1 \mathrm{~b}$ & $51.5 \mathrm{c}$ & $66.2 \mathrm{~b}$ & $57.3 \mathrm{bc}$ \\
Barley - BRS Brau & $20.6 \mathrm{~d}$ & $20.3 \mathrm{a}$ & $59.1 \mathrm{ab}$ & $56.4 \mathrm{c}$ & $66.1 \mathrm{~b}$ & $55.7 \mathrm{c}$ \\
Barley - BRS Cauê & $21.0 \mathrm{~d}$ & $20.4 \mathrm{a}$ & $58.6 \mathrm{ab}$ & $56.5 \mathrm{c}$ & $77.4 \mathrm{ab}$ & $73.1 \mathrm{a}$ \\
Wheat - CD 1440 & $30.1 \mathrm{bc}$ & $10.6 \mathrm{c}$ & $59.3 \mathrm{a}$ & $70.6 \mathrm{a}$ & $83.8 \mathrm{a}$ & $70.2 \mathrm{a}$ \\
Rye - BR 01 & $46.7 \mathrm{a}$ & $11.2 \mathrm{c}$ & $42.1 \mathrm{c}$ & $59.5 \mathrm{bc}$ & $70.4 \mathrm{ab}$ & $59.0 \mathrm{bc}$ \\
Triticale - IPR 111 & $28.5 \mathrm{c}$ & $12.3 \mathrm{c}$ & $59.2 \mathrm{ab}$ & $58.3 \mathrm{c}$ & $68.1 \mathrm{ab}$ & $63.5 \mathrm{~b}$ \\
Triticale - BRS Saturno & $30.0 \mathrm{bc}$ & $12.8 \mathrm{bc}$ & $57.6 \mathrm{ab}$ & $68.1 \mathrm{ab}$ & $76.3 \mathrm{ab}$ & $63.0 \mathrm{~b}$ \\
\hline Average & 30.29 & 14.98 & 55.56 & 60.13 & 72.62 & 63.12 \\
CV, \% & 8.19 & 13.92 & 4.70 & 6.57 & 9.52 & 4.50 \\
P> & $<0.0001$ & $<0.0001$ & $<0.0001$ & $<0.0001$ & 0.0136 & $<0.0001$ \\
\hline
\end{tabular}

Means followed by different lowercase letters, in the same column, are significantly different by Tukey's test at $5 \%$. 
Table 4. Chemical composition of the silage of different winter cereals harvested at the stage of floury grain.

\begin{tabular}{|c|c|c|c|c|c|c|c|}
\hline \multirow{2}{*}{ foods } & \multirow{2}{*}{ Genotype } & MM & $\mathrm{CP}$ & $\mathrm{NDF}$ & $\mathrm{ADF}$ & $\mathrm{DM}$ & TDN \\
\hline & & \multicolumn{6}{|c|}{$\% \mathrm{DM}$} \\
\hline \multirow{8}{*}{ Forage } & White oat - URS Taura & $4.73 \mathrm{ab}$ & $7.49 \mathrm{a}$ & $75.64 \mathrm{a}$ & $40.72 \mathrm{~b}$ & $50.7 \mathrm{ab}$ & $59.33 \mathrm{a}$ \\
\hline & Barley - BRS Brau & $4.60 \mathrm{ab}$ & $7.84 \mathrm{a}$ & $78.25 \mathrm{a}$ & $45.31 \mathrm{ab}$ & $53.5 \mathrm{ab}$ & $56.12 \mathrm{ab}$ \\
\hline & Barley - BRS Cauê & $5.51 \mathrm{a}$ & $7.10 \mathrm{a}$ & $76.69 \mathrm{a}$ & $45.76 \mathrm{ab}$ & $58.4 \mathrm{a}$ & $55.81 \mathrm{ab}$ \\
\hline & Wheat - CD 1440 & $4.05 \mathrm{ab}$ & $5.18 \mathrm{~b}$ & $83.89 \mathrm{a}$ & $50.73 \mathrm{a}$ & $48.4 \mathrm{ab}$ & $52.33 \mathrm{~b}$ \\
\hline & Rye - BR 01 & $3.56 \mathrm{~b}$ & $6.34 \mathrm{ab}$ & $77.78 \mathrm{a}$ & $46.45 \mathrm{ab}$ & $49.4 \mathrm{ab}$ & $55.32 \mathrm{ab}$ \\
\hline & Triticale - IPR 111 & $3.92 \mathrm{ab}$ & $6.88 \mathrm{ab}$ & $79.41 \mathrm{a}$ & $40.34 \mathrm{~b}$ & $48.1 \mathrm{ab}$ & $59.60 \mathrm{a}$ \\
\hline & Triticale - BRS Saturno & $3.93 \mathrm{ab}$ & $6.73 \mathrm{ab}$ & $75.87 \mathrm{a}$ & $43.53 \mathrm{~b}$ & $43.6 \mathrm{~b}$ & $57.37 \mathrm{a}$ \\
\hline & Average & $4.33 \mathrm{~A}$ & $6.79 \mathrm{~A}$ & $78.22 \mathrm{~A}$ & $44.69 \mathrm{~A}$ & $50.31 \mathrm{~B}$ & $56.56 \mathrm{~A}$ \\
\hline \multirow{8}{*}{ Silage } & White oat - URS Taura & $4.22 \mathrm{a}$ & $6.90 \mathrm{a}$ & $59.09 \mathrm{a}$ & $35.89 \mathrm{~b}$ & $58.4 \mathrm{a}$ & $62.72 \mathrm{a}$ \\
\hline & Barley - BRS Brau & $3.88 \mathrm{ab}$ & $7.38 \mathrm{a}$ & $56.71 \mathrm{a}$ & $36.09 \mathrm{ab}$ & $64.5 \mathrm{a}$ & $62.58 \mathrm{ab}$ \\
\hline & Barley - BRS Cauê & $4.24 \mathrm{a}$ & $7.78 \mathrm{a}$ & $56.95 \mathrm{a}$ & $35.18 \mathrm{~b}$ & $65.4 \mathrm{a}$ & $63.22 \mathrm{a}$ \\
\hline & Wheat-CD 1440 & $2.89 \mathrm{~b}$ & $6.49 \mathrm{a}$ & $57.13 \mathrm{a}$ & $37.44 \mathrm{ab}$ & $53.8 \mathrm{a}$ & $61.64 \mathrm{ab}$ \\
\hline & Rye - BR 01 & $3.56 \mathrm{ab}$ & $7.05 \mathrm{a}$ & $57.07 \mathrm{a}$ & $38.02 \mathrm{ab}$ & $60.4 \mathrm{a}$ & $61.23 \mathrm{ab}$ \\
\hline & Triticale - IPR 111 & $3.93 \mathrm{ab}$ & $6.65 \mathrm{a}$ & $59.55 \mathrm{a}$ & $37.12 \mathrm{ab}$ & $54.5 \mathrm{a}$ & $61.86 \mathrm{ab}$ \\
\hline & Triticale - BRS Saturno & $3.31 \mathrm{ab}$ & $6.49 \mathrm{a}$ & $65.23 \mathrm{a}$ & $45.06 \mathrm{a}$ & $56.5 \mathrm{a}$ & $56.30 \mathrm{~b}$ \\
\hline & Average & $3.72 \mathrm{~B}$ & $6.96 \mathrm{~A}$ & $58.82 \mathrm{~B}$ & $37.83 \mathrm{~A}$ & $59.10 \mathrm{~A}$ & $61.36 \mathrm{~A}$ \\
\hline
\end{tabular}

Means followed by different lowercase letters, in the same column, indicate significant differences between genotypes within the same food by Tukey's test at 5\%

Means followed by different uppercase letters, in the same column, indicate significant differences between foods by F-test at 5\%.

On the other hand, barley cv. BRS Brau and cv. BRS Cauê showed the smallest participation of stem in its structure $(20.6 \%$ and $21.0 \%$, respectively), which according to Meinerz et al. (2011a), is explained as it is a small sized crop, what also provides excellent nutritional quality, proved by the digestibility values found herein (Table 4).

Barley cultivars presented the greatest $(\mathrm{P}<0.05)$ participations of leaves in the plant structure, not differing only from white oats. Wheat, both barleys and triticales showed presented greater presence of cobs in the plant structure, which according to Carletto et al. (2015), is due to the genetic breeding imposed on these cultivars for the dual purpose.

This greater participation of cobs in the plant physical structure of wheat presupposes a starch rich food, however, with low protein content, which may be confirmed when observing Table 4, where this presented the lowest content of crude protein
$(5.18 \%)$ in relation to the other forage plants.

In relation to the chemical composition in Table 4 , it is observed that the rye forage had the lowest content of mineral material, differing only from the barley forage cv. BRS Cauê (3.56 \% and $5.51 \%$, respectively).

The white oat and both barleys, as forages, showed the highest contents of crude protein, probably due to the greater proportion of leaves in their composition. According to Horst et al. (2017), a high concentration of leaves implies a greater concentration of digestible nutrients in the dry matter.

Carvalho and Pires (2008) reported that greater changes in the physical composition of forage plants occur due to maturity, where there is a downward trend in the nutritive value with the advance of the cycle because of the lignification of the cell wall and the reduction in participation of leaves in relation to 
stems. There were no differences between forages for neutral detergent fiber, with overall mean of $78.22 \%$. These values are superior to those found by Leão et al. (2017), in winter cereals harvested at the floury grain stage, validating the hypothesis quoted above.

Forage of barley cv. BRS Cauê stood out positively from the other treatments with 58.4\% digestibility (Table 4), similar to the value found by Leão et al. (2017) for the same genotype, which confirms that this is a common characteristic of this cultivar.

Forage of wheat presented the lower content of total digestible nutrients $(52.33 \%)$, possibly for showing greater contents of acid detergent fiber. It is important to consider that forages preserved as silage may have their nutritional value modified because of the adopted methods for their production and preservation and also the microbiological and biochemical phenomena occurring in the process. In general, the silage quality depends on the fermentation pattern, which in turn affects the nutrient concentration and form and the animal intake. The observed variations between forage and silage, as to dry matter, NDF and digestibility justify this fact.

Still in Table 4, there was no significant difference for neutral detergent fiber and crude protein between silages. The silages of barley cv. BRS Cauê and the white oat presented lower values of acid detergent fiber (35.18\% and $35.89 \%$ respectively), while the silage of triticale cv. BRS Saturno had the highest value $45.06 \%$ for the same variable.

The mean values found for neutral detergent fiber in the silages are similar to those described by Fontaneli et al. (2009), but lower than those reported by Lehmen et al. (2014), whose report shows values ranging from $59 \%$ to $74 \%$. This may be a result of the more advanced harvest stage of the present study, which, according to Taiz and Zeiger (2013), causes a substitution of nitrogen compounds by fiber compounds.
The content of neutral detergent fiber in silage was lower $(\mathrm{P}<0,05)$ than in forage and this difference may be because of fermentation, where there is a rupture of the cell wall, contributing to the fiber degradation. This effect may be considered positive to the process for providing soluble carbohydrates to the silage microorganisms and allowing a greater consumption of silage by the animals (LEHMEN et al., 2014).

As for the acid detergent fiber content, silages of barley cv. BRS Cauê and the white oat presented lower values (35.18\% and $35.89 \%$, respectively), but, differed significantly only from the silage of triticale cv. BRS Saturno (45.06\%). Such response is similar to that reported by Lehmen et al. (2014) and Fontaneli et al. (2009).

Except for silage of triticale cv. BRS Saturno, all the other silages presented acid detergent fiber content below $40 \%$, as it is fundamental to keep a good voluntary intake in ruminants (MEINERZ et al., 2011b). It is suggested that with the acid action present during the fermentation process of silage, hydrolysis of the hemicellulose fraction occurred. This is evidenced when we noticed difference for neutral detergent fiber, but not for acid detergent fiber, between forage and silage.

Silage of barley cv. BRS Cauê presented the largest concentration of total digestible nutrients $(63.22 \%)$, differing only from silage of triticale cv. BRS Saturno (56.30\%). Meinerz et al. (2015) reported a suitable percentage of total digestible nutrients ranging between $55.47 \%$ and $63.87 \%$, showing that all the materials of the present study presented satisfactory values for this variable.

Silages of both ryes presented the highest dry matter digestibility ( $53.5 \%$ and $58.4 \%$, respectively), confirming the result described by Fontaneli et al. (2009), who found superiority in barley digestibility $(67.93 \%)$ in relation to black oat, white oat, rye, triticale and wheat.

It is evident in Figure 2 the higher aerobic stability of silage of barley cv. BRS Cauê, wheat 
cv. CD 1440 and rye cv. BR 01 compared to the others, while the other silages destabilized within approximately 32 hours, those already mentioned did not lose stability during the analysis (160 hours).

Figure 2. Evaluation of the time, in hours, for loss of aerobic stability of winter grain silages.

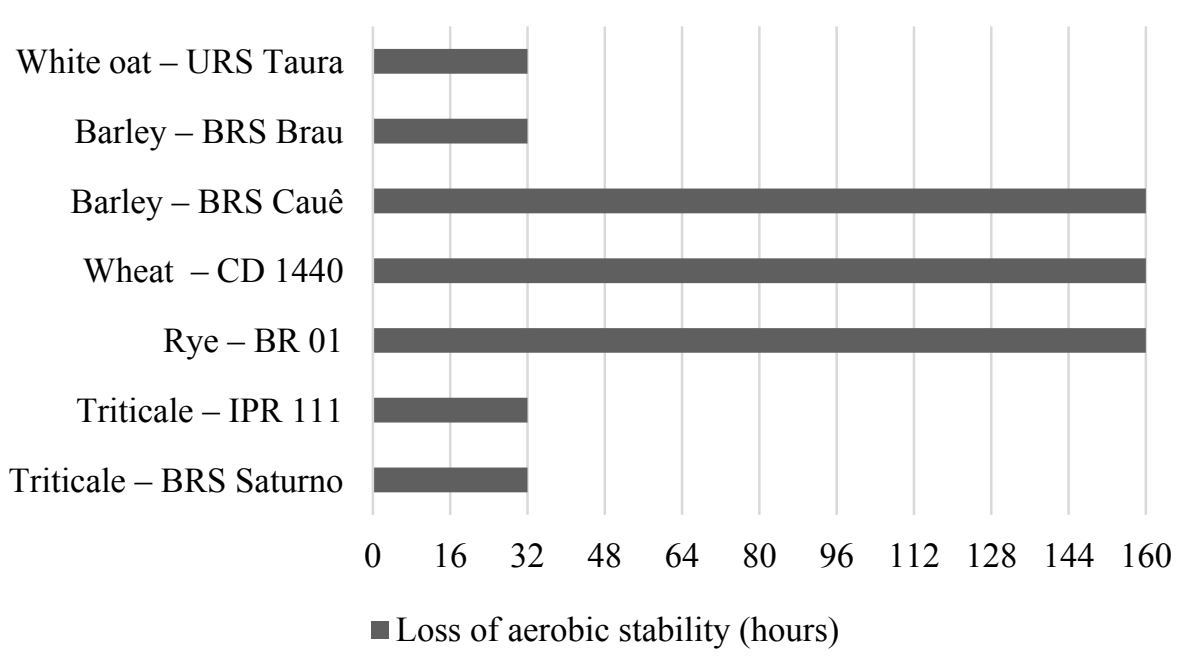

According to Jobim et al. (2009), the lower values of total digestible nutrients presented by barley cv. BRS Cauê, wheat cv. CD 1440 and rye cv. BR 01 may be related to the high aerobic stability time of these silages.

Muck (2010) states that the epiphytic flora of some winter cereals, composed of heterofermentative agents causes higher concentrations of acetic acid 1,2 propanediol, which is transformed into propionic acid. In turn, Leão et al. (2017) suppose that the higher stability attributed to some winter cereal silages may be related to this higher production of organic acids with antifungal potential, thus avoiding the increase in temperature

\section{Conclusions}

Forage of barley, independent on the cultivar, has high content of crude protein, whereas forage of triticale is a more energetic forage. The white oat shows balance in this nutritional aspect.

Silages present higher digestibility and lower content of neutral detergent fiber in relation to forages. The cultivars BR 01, rye, IPR 111, triticale, presented the highest productions of recovered dry biomass and consequently the lowest cost of production, then being more profitable genotypes.

\section{References}

BOLSEN, K. K. Silage technology. In: AUSTRALIAN MAIZE CONFERENCE, 2., 1996, Queensland. Proceedings... Queensland: Gatton College, 1996. p. $1-30$.

CARLETTO, R.; NEUMANN, M.; LEÃO, G. F. M.; HORST, E. H.; ASKEL, E. J. Efeito do manejo de cortes sucessivos sobre a produção e qualidade de grãos de trigo duplo propósito. Revista Acadêmica Ciência Animal, Curitiba, v. 13, n. 7, p. 127-135, 2015. DOI: 10.7213/ academica.13.FC.AO13

CARVALHO, G. G. P.; PIRES, A. J. V. Organização dos tecidos de plantas forrageiras e suas implicações para os ruminantes. Archivos de Zootecnia, Córdoba, v. 57, p. 13-28, 2008.

COMISSÃO DE QUÍMICA E FERTILIDADE DO SOLO - CQFS RS/SC. Manual de adubação e de calagem para os estados do Rio Grande do Sul e Santa Catarina. 10. ed. Porto Alegre: Sociedade Brasileira de Ciência do Solo/Núcleo Regional Sul, 2004. 400 p. 
FLOSS, E. L.; PALHANO, A. L.; SOARES FILHO, C. V.; PREMAZZI, L. M. Crescimento, produtividade, caracterização e composição química da aveia branca. Acta Scientiarum. Animal Sciences, Maringá, v. 29, n. 1, p. 1-7, 2007. DOI: 10.4025/actascianimsci.v29i1.241

FONTANELI, R. S.; FONTANELI, R. S.; SANTOS, H. P.; NASCIMENTO JUNIOR, A.; MINELLA, E; CAIERÃO, E. Rendimento e valor nutritivo de cereais de inverno de duplo propósito: forragem verde e silagem ou grãos. Revista Brasileira de Zootecnia, Viçosa, MG, v. 38, n. 11, p. 2116-2120, 2009. DOI: 10.1590/S151635982009001100007

HORST, E. H. Produção e qualidade nutricional da forragem e da silagem pré-secada de diferentes cereais de inverno colhidos em estádio de pré-florescimento. 2016. Dissertação (Mestrado em Agronomia) - Universidade Estadual do Centro Oeste, Guarapuava.

HORST, E. H.; NEUMANN, M.; SANTOS, J. C.; MAREZE, M.; MIZUBUTI, I. Y.; BUMBIERIS JÚNIOR, V. H. Fiber composition and degradability of green forage and pre-dried silage of cold season cereals harvested in the pre-flowering stage. Semina Ciências Agrárias, Londrina, v. 38, n. 2, p. 2041-2049, 2017. DOI: 10.5433/1679-0359.2017v38n4p2041

JOBIM, C. C.; SILVA, M. S.; CALIXTO JUNIOR, M. Challenges in the utilization of high moisture grains silages for ruminants. In: INTERNATIONAL SYMPOSIUM ON FORAGE QUALITY AND CONSERVATION, 1., 2009, Piracicaba. Proceedings... Piracicaba: FEALQ, 2009. p. 91-108.

KUNG JUNIOR, L.; ROSINLOON, J. R.; RANJIT, K. CHEN, C.M.; GOLT, J.D.; PESED, J.D. Microbial populations, fermentation and products, and aerobic stability of corn silage treated with ammonia or a propionic acid-based preservative. Journal of Dairy Science, Champaign, v. 83, n. 7, p. 1479-1486, 2000. DOI: 10.3168 / jds.S0022-0302 (00) 75020-X

LARGE, E. C. Growth stages in cereals illustration of the Feekes scale. Plant Pathology, Chichester, v. 3, n. 4, p. 128-129, 1954. DOI: 10.1111/j.1365-3059.1954. tb00716.x

LEÃO, G. F. M.; JOBIM, C. C.; NEUMANN, M.; HORST, E. H.; SANTOS, S. K. D.; VENANCIO, B. J.; SANTOS, L. C. Nutritional composition and aerobic stability of winter cereal silage at different storage times. Acta Scientiarum. Animal Sciences, Maringá, v. 39, n. 2, p. 131-136, 2017. DOI: 10.4025/actascianimsci. v39i2.3427

LEHMEN, R. I.; FONTANELI, R. S.; FONTANELI, R. S.; SANTOS, H. P. Rendimento, valor nutritivo e características fermentativas de silagens de cereais de inverno. Ciência Rural, Santa Maria, v. 44, n. 7, p. 11801185, 2014. DOI: $10.1590 / 0103-8478$ cr20130840

MEINERZ, G. R.; OLIVO, C. J.; FONTANELI, R. S.; AGNOLIN, C. A.; FONTANELI, R. S.; HORST, T.; VIEGAS, J.; BEM, C. M. Valor nutritivo da forragem de genótipos de cereais de inverno com duplo propósito. Revista Brasileira de Zootecnia, Viçosa, MG, v. 40, n. 6, p. 1173-1180, 2011a. DOI: 10.1590/S151635982011000600003 .

MEINERZ, G. R.; OLIVO, C. J.; NÖRNBERG, J. L.; VIÉGAS, J.; AGNOLIN, C. A.; SCHEIBLER, R. B.; SKONIESK, F. R.; ZIECH, M. F.; QUATRIN, M. P. Utilização da biomassa remanescente de pastagens de estação fria para produção de forragem conservada. Arquivo Brasileiro de Medicina Veterinária e Zootecnia, Belo Horizonte, v. 67, n. 5, p. 1390-1398, 2015. DOI: 10.1590/1678-4162-7418.

MEINERZ, J. R.; OLIVO, C. J.; VIÉGAS, J.; NÖRNBERG, J. L.; AGNOLIN, C. A.; SCHEIBLER, R. B.; HORST, T.; FONTANELI, R. S. Silagem de cereais de inverno submetidos ao manejo de duplo propósito. Revista Brasileira de Zootecnia, Viçosa, MG, v. 40 , n. 10 , p. $2097-2104,2011$ b. DOI: $10.1590 /$ S151635982011001000005 .

MUCK, R. E. Silage microbiology and its control through additives. Revista Brasileira de Zootecnia, Viçosa, MG, v. 39, n. (supl. especial), p. 183-191, 2010. DOI: 10.1590/ S1516-35982010001300021

NOCEK, J. E. In situ and other methods to estimate ruminal protein and energy digestibility. A review. Journal of Dairy Science, Champaign, v. 71, n. 8, p. 2051206, 1988. DOI: 10.3168/jds.S0022-0302(88)79781-7

POTT, C. A.; MÜLLER, M. M. L.; BERTELLI, P. B. Adubação verde como alternativa agroecológica para recuperação da fertilidade do solo. Revista Ambiência, Guarapuava, v. 3, n. 1, p. 51-63, 2007.

SILVA, D. J.; QUEIROZ, A. C. Análise de alimentos, métodos químicos e biológicos. 3. ed. $4^{\mathrm{a}}$ reimpressão. Viçosa, MG: Universidade Federal de Viçosa, 2009. 235 p.

TAIZ, L.; ZEIGER, E. Fisiologia vegetal. 5. ed. Porto Alegre: ArtMed, 2013. 954 p.

TAYLOR, C. C.; KUNG JUNIOR, L. The effect of Lactobacillus buchneri on fermentation and aerobic stability of high moisture corn in laboratory silos. Journal of Dairy Science, Champaign, v. 85, n. 6, p. 1526-1532, 2002. DOI: $10.3168 / j d s . S 0022-0302(02) 74222-7$

WOOLFORD, M. K.; PAHLOW, G. The silage fermentation. New York: Springer, 1998. 306 p. 
